\title{
Correction to: KDM6B promotes ESCC cell proliferation and metastasis by facilitating C/EBP $\beta$ transcription
}

Mei Qin ${ }^{1 \dagger}$, Fei Han ${ }^{2 \dagger}$, Jian Wư ${ }^{2}$ Feng-xia Gao ${ }^{1}$, Yuan Li ${ }^{2}$, De-xin Yan², Xue-mei He ${ }^{3}$, Yang Long ${ }^{3}$, Xiao-ping Tang ${ }^{3}$, De-lian Ren ${ }^{1}$, Yan Gao ${ }^{1 *}$ and Tian-yang Dai ${ }^{2^{*}}$

\section{Correction to: BMC Cancer 21, 559 (2021) https://doi.org/10.1186/s12885-021-08282-w}

Following publication of the original article [1], the authors identified an error in the author affiliation of Tian-yang Dai. The affiliation, should be:

2 Department of Thoracic Surgery, The Affiliated Hospital of Southwest, Medical University, Sichuan, Luzhou, China.

The author group has been updated above and the original article [1] has been corrected.

\section{Author details}

'Department of Immunology, Basic Medicine College, South West Medical University, Luzhou, Sichuan, China. ${ }^{2}$ Department of Thoracic Surgery, The Affiliated Hospital of Southwest, Medical University, Luzhou, Sichuan, China. ${ }^{3}$ Experimental Medicine Center, The Affiliated Hospital of Southwest Medical University, Luzhou, Sichuan, China.

Published online: 05 August 2021

\section{Reference}

1. Qin M, Han F, Wu J, et al. KDM6B promotes ESCC cell proliferation and metastasis by facilitating C/EBP $\beta$ transcription. BMC Cancer. 2021;21:559 https://doi.org/10.1186/s12885-021-08282-w.

\footnotetext{
The original article can be found online at https://doi.org/10.1186/s12885021-08282-w.

* Correspondence: gaoyan7000@sina.com; daitianyang0502@sina.com

${ }^{+}$Mei Qin and Fei Han contributed equally to this work.

'Department of Immunology, Basic Medicine College, South West Medical University, Luzhou, Sichuan, China

${ }^{2}$ Department of Thoracic Surgery, The Affiliated Hospital of Southwest, Medical University, Luzhou, Sichuan, China

Full list of author information is available at the end of the article
}

(c) The Author(s). 2021 Open Access This article is licensed under a Creative Commons Attribution 4.0 International License, which permits use, sharing, adaptation, distribution and reproduction in any medium or format, as long as you give appropriate credit to the original author(s) and the source, provide a link to the Creative Commons licence, and indicate if changes were made. The images or other third party material in this article are included in the article's Creative Commons licence, unless indicated otherwise in a credit line to the material. If material is not included in the article's Creative Commons licence and your intended use is not permitted by statutory regulation or exceeds the permitted use, you will need to obtain permission directly from the copyright holder. To view a copy of this licence, visit http://creativecommons.org/licenses/by/4.0/ The Creative Commons Public Domain Dedication waiver (http://creativecommons.org/publicdomain/zero/1.0/) applies to the data made available in this article, unless otherwise stated in a credit line to the data. 